\title{
Article \\ Sustainability in Residential High-Rise Building Using Knowledge Management of Critical Success Technique
}

\author{
Yossakorn Chonratana and Vuttichai Chatpattananan*
}

Department of Civil Engineering, School of Engineering, King Mongkut's Institute of Technology Ladkrabang,
Bangkok 10520, Thailand; 63601251@kmitl.ac.th
* Correspondence: vuttichai.ch@kmitl.ac.th

\begin{abstract}
Sustainability is very important in business. The residential high-rise building all firms wanted to successful and sustainability in business. There is need the construction to completed low time, low cost and high quality in construction work. Therefore, real estate developers must find various strategies to use in construction projects to achieve goals and success of the firm. The purpose of this study was to indicate the very importance of knowledge management can lead to sustainability in business. Analyze 14 critical success to sustainability in residential high-rise building projects, collected questions from literature review, and survey in deep interview senior managers of 15 projects real estate development firms listed on the stock market of Thailand. Budget building more than 1000 million baht per project. From conceptual frame work five foundations integrated to knowledge management of critical success (KMITL PROCESS) used made tool survey in deep interview the critical success to sustainability in residential high-rise building project from project managers. Used IBM SPSS evaluated the critical success to sustainability. Found was one very important of critical success to sustainability, which was quality of products $\bar{x}=4.83$. All 14 critical success to sustainability was found can applied made the knowledge management of critical success to sustainability in residential high-rise building project in firm. Especially in the field of construction managements project can used improve of all construction projects.
\end{abstract}

Keywords: residential high-rise building; critical success to sustainability; KMITL PROCESS

\section{Introduction}

Construction industry is considered sector of the economy very important role in the development and stimulation of the country. For support the needs sufficient to the country expansion in house due to the continuous increase of the population. Therefore, real estate developers residential high-rise building in the country must compete intensely in the business. Real estate developers have to develop organization and used strategies in the firm able to dominate the market in residential high-rise building of customers and create continuously satisfaction for success to sustainability in the high-rise building business [1-6]. But residential high-rise buildings in the category have several obstacles in the project because is large project. Have problems before construction, obstacles during construction and obstacles after construction. Real estate developed residential high-rise building properties have to find strategies in order to success continuously the project. Although ever success in the old project the real estate developers but face the old problems and old obstacles when going to build next construction project with similar characteristics still have to start new idea and plan new action. Because real estate developer residential high-rise buildings lack with knowledge management data from completed projects. When have resignation of employees and project managers was have knowledge and experience in the residential high-rise building. The real estate developer residential high-rise building face to begin several old problems in the next projects [7$11]$. 
This research would like to indicated the experience and knowledge in the residential high-rise buildings completed in project is very important. Should be stored and managed in the knowledge and experience carried from the completed project. Collected used continuously for maximum advantages in the firm. The firm able to useful in the residential high-rise building business continuously and increase satisfaction to customers for sustainability in business [12,13]. Although have several changes internal and external of firm. The firm can continuously to leader the residential high-rise building in business. Towards the firm to goals and success on sustainability.

\section{Literature Review}

Sustainability in business is desire in business. The executive of residential high-rise building wanted to leader in business and sustainability. Residential high-rise building projects requires the find for strategies in terms of low time, low cost and high quality to maximize the advantages of the organization [12]. Project managers must implement strategy of all dimensions and critical success used management the residential high-rise building project to meet objectives of firm [2-6]. Project managers solve several obstacles in residential high-rise building projects to success [4]. Property developers should focus on compiled the knowledges and experiences of critical success in project from project managers and employees. Knowledges and experiences should be systematically stored can useful in the next projects [7-11]. Transfer knowledges and experiences is very importance trained to employees of all departments in the firm. Everyone can access knowledges of critical success in residential high-rise building projects [13]. Support learns in the firm of critical success to sustainability. Although must face several changes from internal and external factors involved. The firm still can goal and success on sustainability [3].

Integrated sustainability in residential high-rise building project have to adjust strategies for new management system within the firm. Although have several changes of the world but knowledge management is very importance forever. Therefore, the firm should be made knowledge management continuously.

\subsection{Knowledge Management (KM)}

Knowledge management is the collection of knowledge exists in the organization. Which are scattered in the person or documents in the residential high-rise buildings project have already developed into system. Everyone in the firm can access knowledge management in data base. Integrated knowledge management of the organization can help to develop work, develop people, develop the organization for work effectively in accordance with the goals and success project on Figure 1 [7-11].

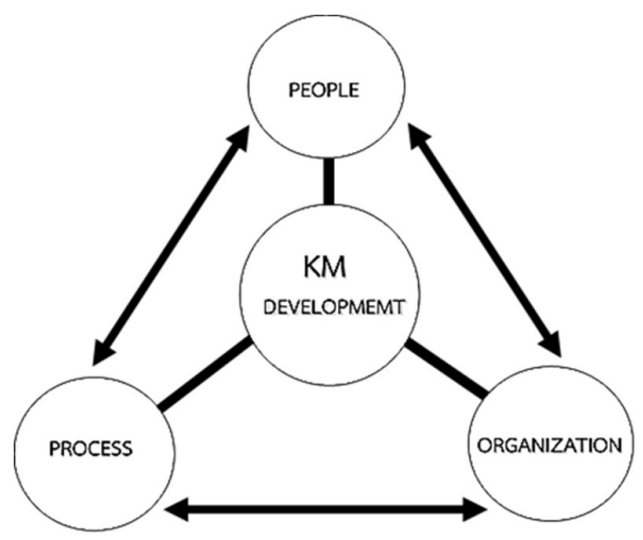

Figure 1. Integrated knowledge management for development process, development people, development organization. 
Knowledge has 2 types:

1. Tacit knowledge is knowledge gained from experience. Individual was talent or instinct for understanding things is knowledge cannot be easily conveyed in words or written, such as work skills, craftsmanship, or critical think [7-11].

2. Explicit knowledge is knowledge can be gathered and transmitted through various such as written records, theories, manuals, and sometimes referred to concrete knowledge [7-11].

Real estate developer is very importance to collect information from Tacit Knowledge and Explicit Knowledge of employees and project managers collected the knowledge systematic might use technology to helped in stored and transferred knowledge of critical success in efficiency for the organization. The firm must still be promoted organization constantly learns constantly.

Knowledge management should be five actions (KMITL PROCESS) to success sustainability.

\subsubsection{Knowledge Process (K)}

Knowledge Process refers to the process in obtained data to the objectives. Which can be divided data collection from secondary and primary sources used interview tools, surveys, observations, filled in questionnaires, reports and documents [7-11].

\subsubsection{Management Process (M)}

Management Process refers to the process monitored data system. For easier planned data and easier controls data to success in objectives firm [12-13].

\subsubsection{Information Process (I)}

Information Process refers to the process operated brought knowledge data to everyone in firm such as document information, document conditions, document control, form of information, operated instructions, knowledge data, media, ideas, perception for success in objectives and goals of organization [14].

\subsubsection{Technology Process (T)}

Technology Process is used of knowledge technique, digital tools, machine tool, IoT, big data, Application in the work to help the work for the better, faster and to increase the efficiency and productivity of the work [15].

\subsubsection{Leaning Process (L)}

Learning is the change in behavior due to experience differently change in behavior both externally and internally. Behavioral changes can be of 4 types such as (1) doing new behaviors (2) undoing behavior (3) increasing old behaviors and (4) reducing old behavior. Learning will create knowledge skills and attitudes. Learning is important for all human beings, all genders, ages, nationalities, religions and all professions. Development society and humanity both in living, working and living together smoothly and peacefully. Caused by the accumulation of learning has been passed down through generations from the past to the present. Choose different methods enable learners to effectively and efficiently appropriate for learner. Learn might difference with physically, emotionally, socially, intellectually and culture [16].

\subsection{Sustainability Management (SM)}

Sustainability management system is process integrates sustainability vision, strategies, action plans and actions into daily operations. This administrative system is tool for executives, organizational units, business units, operating areas and operational units in prioritizing and planning operations. Which development guideline to follow 
check the progress accorded to goals in the organization [17]. Sustainability management is management approach integrates economic, environmental and social efficiency with operations in long-term and support cooperation and trust of all parties in the organization $[18,19]$. Sustainability management is related to strategy responsibility project feasibility decisions management for operational efficiency better risk management. Increased employee relations in the organization and corporate reputation overall involves the pursuit in long-term with responsibility management in environmental and social. The key to sustainability business development is high professional and business values. Organizational should be useful from Hierarchy of Sustainability Management System to success sustainability in the firm on Figure 2 [20].

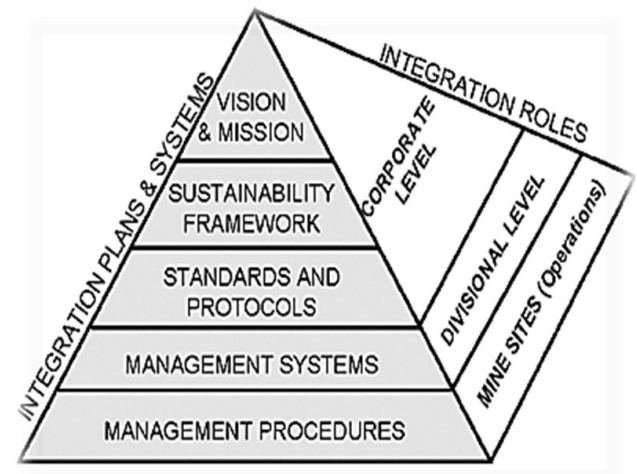

Figure 2. Hierarchy of Sustainability Management System [20].

From the relevant theories of knowledge management and sustainability management. Therefore, made the conceptual framework on Figure 3 for integrated to knowledge management of critical success use to advantages and strategies for manage in residential high-rise building projects to success sustainability in objective firm.

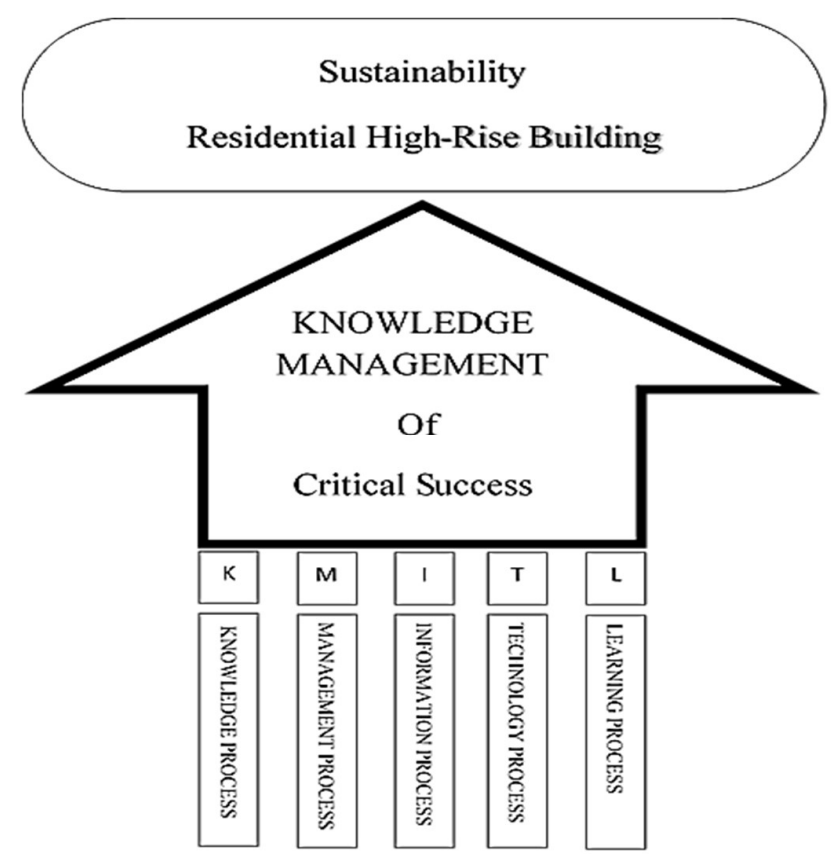

Figure 3. Five Foundations Integrate to Knowledge Management of Critical Success [KMITL PROCESS]. 
Conceptual framework in Figure 3 five foundations Integrate to knowledge management of critical success [KMITL PROCESS]. Integrated from knowledge management and sustainability management from literature review for search the critical success to sustainability in residential high-rise building project for this research on Table $1[17,19]$. The in deep interview tool by selected questions based on the consistency from the literature review, books, documents, articles and related research results related from 3 or more people prepare tool in deep interview and survey with project managers which management success in residential high-rise building project and used the data from the in deep interview for analysis. Used the results from the analysis made knowledge management of critical success to sustainable in residential high-rise building project. Which many firms can made is strategy into sustainability in residential high-rise building all projects.

Table 1. Critical success to sustainability questions from the study of literature and related data.

\section{Critical Success to Sustainability}

Quality construction management in the project.

Cost construction management in the project.

Management information in the project.

Time construction management in the project.

Transfer residential room to customer in the project.

Management procurement materials and equipment in the project.

Claims management in the area adjacent in the project.

Management of dispute resolution in the project.

Management main structure building in the project.

Health and safety management during construction in the project.

Management transportation system in the project.

Strategies bidding contractor work in the project.

Experience bidding for contractors in the project.

Management personnel resources in the project.
Knowledge Base (Theory)
[25-27]

[16,28-29]

[30-32]

[33-38]

[39-43]

[44-48]

[44-48]

[49-51]

$[52-54]$

[55-57]

[58-60]

[58-60]

[61-64] 


\section{Resource Method}

This research is survey research to collect data on the critical success to sustainability in residential high-rise building project for analysis. Collected to provide knowledge of critical success to sustainability in residential high-rise building project management. This is research to be useful and can used strategy for the management in residential high-rise building all projects. Method for conducting research.

\subsection{Population and sample used}

Population and sample used in this research was 15 projects in residential high-rise building projects with project value of more than 1,000 million baht, listed on the stock market of Thailand is success already.

\subsection{Research Instruments}

3.2.1 The characteristics of the instruments used in this research in deep interviews which were divided into 3 steps.

- Part 1 Deep interview form about the interviewer status of project managers.

- Part 2 Deep interview on the critical success to sustainability in residential highrise building projects. The deep interview form was a rated scale with 1 question, with criteria for determined the weight of the assessment at 5 levels according to the Likert Scale method show in Table 3.

- Part 3 Deep interview with comments and other suggestions. The deep interview format is open-ended.

3.2.2. Created research tools used to in deep interview, divided into steps in this order.

- Study the principles of creating deep interview form conceptual framework in Figure 3.

- Study information from literature books, documents, articles and related research results. Guideline to create deep interview form in Table 1.

- Determine the subject and scope of the questions in accordance with the objectives and benefits of the research.

- Create draft interview form show in Table 2.

- The researcher brought the draft questionnaire with the assessment form to the experts. knowledge and experience in the research field to consider the interview form for 3 people to test the accuracy content coverage and accuracy in the deep interview the researcher used the assessment form to calculate the questionnaire accuracy, both the critical success to suitability of the content was between 2.003.00 and the accuracy of used the language calculation was between 2.00-3.00 from average score of 3.00 , the result after calculated the critical success to suitability and the correctness of the language expressions. The researchers took these values together with an expert assessment to be used guideline for improved the interview form.

- The researcher used the draft interview form that has been edited by experts. Go for a try-out interview with a population group that is similar to the population wanted to study, totaling 15 sets.

- Calculate the discrimination power and confidence value of the draft questionnaire after the trial (Try-Out). The interview form is a check list (Check List) will calculate the discriminant value. (Discrimination) by analyzing the standard deviation (Standard Deviation: SD) appeared to be between 0.479-0.830 in the questionnaire which is a rated scale to calculate the confidence of the questionnaire. (Reliability) by analyzed the alpha coefficient, appears that the value is 0.838 . 
- The interview form was revised according to the results of the analysis and confidence of the interview form before it was put into practice.

Table 2. Example form Part 2 Critical success to sustainability in residential high-rise building.

Level

Critical Success to Sustainability

\begin{tabular}{|c|c|c|c|c|}
\hline 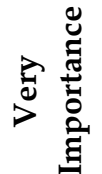 & $i_{0}^{i}$ & 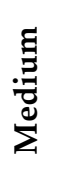 & 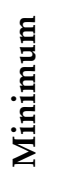 & 芯 \\
\hline
\end{tabular}

Quality construction management in the project.

Cost construction management in the project.

Management information in the project.

Time construction management in the project.

Transfer residential room to customer in the

project.

Management procurement materials and

equipment in the project.

Claims management in the area adjacent in the

project.

Management of dispute resolution in the project.

Management main structure building in the

project.

Health and safety management during

construction in the project.

Management transportation system in the

project.

Strategies bidding contractor work in the project.

Experience bidding for contractors in the project.

Management personnel resources in the project.

\subsection{Data Collection}

The researcher conducted data collection in 2 steps.

- The researcher has contacted the project manager of a residential high-rise building has been completed to collect the deep interview data.

- The researcher used the in deep interview form to check the completeness of the in deep interview form in Table 2 and analyzed the statistical data with a computer.

\subsection{Statistics Used in Statistical Analysis}

This research analyzed the statistical data with the IBM SPSS software package. The collected in deep interview data was converted into a numeric code (Code) and saved into the program to perform the data analysis in 2 steps sequentially. episode as follows

Step 1. Calculate the critical success to sustainability in residential high-rise building project from the questionnaire part 2 by Likert scale method, using the average method (Mean: $\bar{x}$ ) and Standard Deviation (SD). In the interpretation of the critical success to sustainability priorities are divided into two forms, the result show in Table 4. 
- $\quad$ Prioritizing the critical success to sustainability with a higher average score The mean (Average; $\bar{x}$ ) uses the formula.

$\bar{x}$ : represents the mean.

$$
\bar{x}=\left(\sum x i\right) / N
$$

xi: represents answer score.

$\mathrm{N}$ : is the number of members in that group.

$\sum x$ : represents the sum of all answer scores.

- $\quad$ Prioritizing the critical success to sustainability with less standard deviations The standard deviation (Standard Deviation; SD) uses the formula.

$$
\left.\mathrm{SD}=\left[\mathrm{N}\left(\sum \mathrm{xi}\right)^{\wedge} 2-\left(\sum \mathrm{xi}\right)^{\wedge} 2\right)\right]^{\wedge 1 / 2} /[\mathrm{N}(\mathrm{N}-1)]
$$

SD: stands for standard deviation.

xi: represents answer score.

$\mathrm{N}$ : is the number of members in that group.

$\sum x$ : is the sum of all answer scores.

Table 3. Criteria for graded of critical success to sustainability.

\begin{tabular}{cl}
\hline $\begin{array}{c}\text { Critical Success to } \\
\text { Sustainability }\end{array}$ & Score Weight of the Answer \\
\hline Least & Equal to 1 point \\
\hline Minimum & Equal to 2 points \\
\hline Medium & Equal to 3 points \\
\hline Very & Equal to 4 points \\
\hline Very Importance & Equal to 5 points \\
\hline
\end{tabular}

Criteria for graded of critical success to sustainability priority score are defined as the follow score ranges.

\begin{tabular}{cc}
\hline Score of 1.00-1.49 & means is least of critical success to sustainability \\
\hline Score of 1.50-2.49 & means is minimum of critical success to sustainability \\
\hline Score of 2.50-3.49 & means is medium of critical success to sustainability \\
\hline Score of 3.50-4.49 & means is very of critical success to sustainability \\
\hline Score of 4.50-5.00 & means is very important of critical success to \\
sustainability
\end{tabular}

Step 2. Data for other opinions and recommendations on the critical success to sustainability in the residential high-rise building projects from part 3 of the questionnaire. Content analysis and summarizes frequency and present on discussion and implication.

\section{Result}

From data analysis of in deep interviews from the project managers of 15 project in residential high-rise building projects with project value of more than 1000 million baht, listed on the stock market of Thailand. There are five criteria for critical success to sustainability the weight of the assessment according by Likert Scale method in Table 3. The data was analyzed using the IBM SPSS software package. The results of critical 
success to sustainability in residential high-rise building projects from the data analysis shown in Table 4.

Table 4. Results from research on the critical success to sustainability in residential high-rise building projects.

\begin{tabular}{|c|c|c|c|c|}
\hline & Critical Success to Sustainability & $\overline{\bar{X}}$ & SD. & Result \\
\hline 1 & $\begin{array}{l}\text { Quality construction management in the } \\
\text { project. }\end{array}$ & 4.83 & 0.408 & $\begin{array}{c}\text { Very } \\
\text { Importance }\end{array}$ \\
\hline 2 & $\begin{array}{l}\text { Cost construction management in the } \\
\text { project. }\end{array}$ & 4.49 & 0.548 & Very \\
\hline 3 & Management information in the project. & 4.49 & 0.548 & Very \\
\hline 4 & $\begin{array}{l}\text { Time construction management in the } \\
\text { project. }\end{array}$ & 4.49 & 0.548 & Very \\
\hline 5 & $\begin{array}{l}\text { Transfer residential room to customer in the } \\
\text { project. }\end{array}$ & 4.33 & 0.516 & Very \\
\hline 6 & $\begin{array}{l}\text { Management procurement materials and } \\
\text { equipment in the project. }\end{array}$ & 4.33 & 0.516 & Very \\
\hline 7 & $\begin{array}{l}\text { Claims management in the area adjacent in } \\
\text { the project. }\end{array}$ & 4.17 & 0.408 & Very \\
\hline 8 & $\begin{array}{l}\text { Management of dispute resolution in the } \\
\text { project. }\end{array}$ & 4.00 & 0.000 & Very \\
\hline 9 & $\begin{array}{l}\text { Management main structure building in the } \\
\text { project. }\end{array}$ & 3.83 & 0.408 & Very \\
\hline 10 & $\begin{array}{l}\text { Health and safety management during } \\
\text { construction in the project. }\end{array}$ & 3.83 & 0.408 & Very \\
\hline 11 & $\begin{array}{l}\text { Management transportation system in the } \\
\text { project. }\end{array}$ & 3.33 & 0.516 & Medium \\
\hline 12 & $\begin{array}{l}\text { Strategies bidding contractor work in the } \\
\text { project. }\end{array}$ & 3.33 & 0.516 & Medium \\
\hline 13 & $\begin{array}{l}\text { Experience bidding for contractors in the } \\
\text { project. }\end{array}$ & 3.17 & 0.753 & Medium \\
\hline 14 & $\begin{array}{l}\text { Management personnel resources in the } \\
\text { project. }\end{array}$ & 3.00 & 0.632 & Medium \\
\hline
\end{tabular}

The results of sustainability in residential high-rise building using knowledge management of critical success techniques.

1. Sustainability in residential high-rise building using knowledge management of critical success techniques from the in deep interview has 1 Very importance.

1.1. Quality construction management in the project. $(\bar{x}=4.83)$

2. Sustainability in residential high-rise building using knowledge management of critical success techniques from the in deep interview has 9 Very.

2.1. Cost construction management in the project. $(\bar{x}=4.49)$

2.2. Management information in the project. $(\bar{x}=4.49)$

2.3. Time construction management in the project. $(\bar{x}=4.49)$

2.4. Transfer residential room to customer in the project. $(\bar{x}=4.33)$

2.5. Management procurement materials and equipment in the project. $(\bar{x}=4.33)$

2.6. Claims management in the area adjacent in the project. $(\bar{x}=4.17)$

2.7. Management of dispute resolution in the project. $(\bar{x}=4.00)$

2.8. Management main structure building in the project. $(\bar{x}=3.83)$ 
2.9. Health and safety management during construction in the project. $(\bar{x}=3.83)$

3 Sustainability in residential high-rise building using knowledge management of critical success techniques from the in deep interview has 4 Medium.

3.1 Management transportation system in the project. $(\bar{x}=3.33)$

3.2 Strategies bidding contractor work in the project. $(\bar{x}=3.33)$

3.3 Experience bidding for contractors in the project. $(\bar{x}=3.17)$

3.4 Management personnel resources in the project. $(\bar{x}=3.00)$

\section{Discussion and Implication}

In this research, the results can be used to guide line the conceptual framework of knowledge management of critical success to sustainability in all fields. Especially in the residential high-rise building project. The results obtained from analysis of the in deep interview results in Part 2 can be adapted to suit the firm. But with the location, geography, society, environment in each construction project is different. From the survey results in the part 3. There are additional suggestions from in deep interviews from project managers on various problems and different solutions because project differs due to location, geography, society, and environment such as coordination issues government job, regarding the activities of coordinating in relation to the neighboring areas of the construction project, stored materials in the project for easy construction and checked the remain amount of materials, equipment and waste collection in the construction project to prevent fire problems and pollution problems.

Therefore, every firm should continuously collect the knowledge from critical success to sustainability for match the goals and objectives in firm.

\section{Conclusions}

From the conceptual framework five found integrate to knowledge management of critical success (KMITL PROCESS) in Figure 3. Made tool survey in deep interview in research found the critical success to sustainability in residential high-rise building, the very importance of critical success to sustainability is obtained has 1 priority, namely, quality construction management in the project $(\bar{x}=4.83)$, and the very level has 9 of critical success to sustainability, which cost construction management in the project $(\overline{\mathrm{x}}=$ $4.49)$, management information in the project $(\bar{x}=4.49)$, time construction management in the project $(\bar{x}=4.49)$, transfer residential room to customer in the project $(\bar{x}=4.33)$, management procurement materials and equipment in the project $(\bar{x}=4.33)$, claims management in the area adjacent in the project $(\bar{x}=4.17)$, management of dispute resolution in the project $(\bar{x}=4.00)$, management main structure building in the project $(\bar{x}$ $=3.83)$, health and safety management during construction in the project $(\bar{x}=3.83)$.

Therefore, the critical success for all 10 of critical success can be applied data to sustainability in residential high-rise building using knowledge management of critical success technique toward success sustainability in firms and integrated with the conceptual framework in this research in Figure 3 integrate in several projects to sustainability in the construction project for all firms.

Author Contributions: Conceptualization, Y.CH and V.CH.; methodology, Y.CH and V.CH.; software, Y.CH and V.CH.; validation, Y.CH and V.CH.; formal analysis, Y.CH and V.CH.; investigation, Y.CH and V.CH.; resources, Y.CH and V.CH.; data curation, Y.CH and V.CH.; writing-original draft preparation, Y.CH and V.CH.; writing-review and editing, Y.CH and V.CH.; visualization, Y.CH and V.CH.; supervision, Y.CH and V.CH.; project administration, Y.CH and V.CH.; All authors have read and agreed to the published version of the manuscript.

Funding: The publication cost was supported by School of Engineering, King Mongkut's Institute of Technology Ladkrabang.

Conflicts of Interest: The authors declare no conflict of interest. 


\section{References}

1. Wheelen, L.T.; Hunger, J.D.; Hoffman, A.N.; Bamford, C.E. Concepts in Strategic Management and Business Policy; Pearson Education Limited: London, UK, 2015.

2. Porter, M.E. Competitive Strategy: Techniques for Analyzing Industries and Firms; Free Press: New York, NY, USA, 1980.

3. Ho, P.H.K. Analysis of competitive environments, business strategies, and performance in Hong Kong's construction industry. J. Manag. Eng. 2016, 32, 04015044.

4. Johnson, G.; Scholes, K. Exploring Corporate Strategy: Text and Cases; Prentice Hall: Hertfordshire, UK, 1989.

5. McGee, J.E.; Dowling, M.J.; Megginson, W.L. Cooperative strategy and new venture performance: The role of business strategy and management experience. J. Strateg. Manag. 1995, 16, 565-580.

6. Ghodrati, N.; Yiu, T.W.; Wilkinson, S.; Shahbazpour, M. Role of management strategies in improving labor productivity in general construction projects in New Zealand: Managerial perspective. J. Manag. Eng. 2018, 34, 04018035.

7. Shadan, K. Construction Project Management Handbook; Federal Transit Administration: Washington, DC, USA, 2012.

8. Cheng, J.; Proverbs, D.G. The impact of strategic decisions on construction client satisfaction. In Proceedings of the 20th Annual ARCOM Conference, Edinburgh, UK, 1-3 September 2004; Volume 2, pp. 931-938.

9. Kärnä, S.; Junnonen, J.-M.; Sorvala, V.-M. Modelling structure of customer satisfaction with construction. J. Facil. Manag. 2009, 7, 111-127.

10. Okudan, O.; Budayan, C.; Dikmen, I. A knowledge-based risk management tool for construction projects using case-based reasoning. Expert Syst. Appl. 2021, 173, 114776.

11. Wibowo, M.A.; Waluyo, R. Knowledge Management Maturity in Construction Companies. Procedia Eng. 2015, 125, 89-94.

12. Ding, L.Y.; Zhong, B.T.; Wu, S.; Luo, H.B. Construction risk knowledge management in BIM using ontology and semantic web technology. Saf. Sci. 2016, 87, 202-213.

13. Du, M.; Qiu, F.; Xu, W. Construction of enterprises' financial knowledge management system (EFKMS). Procedia Environ. Sci. 2011, 11, 1240-1244, doi:10.1016ij.proenv.2011.12.186.

14. Belay, A.M.; Torp, O; Thodesen, C. Managing concurrent construction projects using knowledge management and set-based thinking. Procedia Eng. 2016, 164, 235-242, doi:10.1016/j.proeng.2016.11.615.

15. Bossink, B. Learning strategies in sustainable energy demonstration projects: What organizations learn from sustainable energy demonstrations. Renew. Sustain. Energy Rev. 2020, 131, 110025, doi:10.1016ij.rser.2020.110025.

16. Min, T.; Yuanbiao, H.; Zhiguo, L.; Wenjian, Z. Development of management information system of geodrilling construction. Procedia Eng. 2014, 73, 118-126.

17. Valdes-Vasquez, R.; Klotz, L.E. Sustainability considerations during planning and design: Framework of processes for construction projects. J. Constr. Eng. Manag. 2013, 139, 80-89.

18. Karji, A.; Woldesenbet, A.; Khanzadi, M.; Tafazzoli, M. Assessment of social sustainability indicators in masshousing construction: A case study of Mehr housing project. Sustain. Cities Soc. 2019, 50, 101697.

19. Mahmoudi, R.; Shetab-Boushehri, S.-N.; Hejazi, S.R.; Emrouznejad, A. Determining the relative importance of sustainability evaluation criteria of urban transportation network. Sustain. Cities Soc. 2019, 47, 101493, doi:10.1016ij.scs.2019.101493.

20. Botin, J.A. (Ed.) Sustainable management: A strategic challenge for a global minerals and metals industry. In Proceedings of the Copper 2010, Hamburg, Germany, 6-10 June 2010.

21. Mashwama, N.; Aigbavboa, C.; Thwala, D. An assessment of the critical success factor for the reduction of cost of poor quality in construction projects in Swaziland. Procedia Eng. 2017, 196, 447-453.

22. Qing, L.; Rengkui, L.; Jun, Z.; Quanxin, S. Quality risk management model for railway construction projects. Procedia Eng. 2014, 84, 195-203, doi:10.1016ij.proeng.2014.10.426.

23. Lukichev, S.; Romanovich, M. The quality management system as a key factor for sustainable development of the construction companies. Procedia Eng. 2016, 165, 1717-1721, doi:10.1016ij.proeng.2016.11.914.

24. Panuwatwanich, K.; Nguyen, T.T. Influence of total quality management on performance of Vietnamese construction firms. Procedia Eng. 2017, 182, 548-555, doi:10.1016ij.proeng.2017.03.151.

25. Nikolay, I. A study on optimization of nonconformities management cost in the quality management system (QMS) of smallsized enterprise of the construction industry. Procedia Eng. 2016, 153, 228-231, doi:10.1016ij.proeng.2016.08.107.

26. Nasereddin, M.; Price, A. Addressing the capital cost barrier to sustainable construction. Dev. Built Environ. 2021, 7, 100049, doi:10.1016/j.dibe.2021.100049.

27. Salem, D.; Bakr, A.; El Sayad, Z. Post-construction stages cost management: Sustainable design approach. Alex. Eng. J. 2018, 57, 3429-3435, doi:10.1016ij.aej.2018.07.014.

28. Eroshkin, S.Y.; Koryagin, N.D.; Kovkov, D.V.; Panov, D.V.; Sukhorukov, A.I. The paradigm of the integration of different types of management information systems in investment and construction company implementing the project approach. Procedia Comput. Sci. 2017, 103, 605-608. (CrossRef).

29. Volkov, A.; Chelyshkov, P.; Lysenko, D. Information management in the application of BIM in construction. stages of construction. Procedia Eng. 2016, 153, 833-837, doi:10.1016ij.proeng.2016.08.251.(CrossRef). 
30. Chin, L.S.; Hamid, A.R.A. The practice of time management on construction project. Procedia Eng. 2015, 125, 32-39.

31. Gładysz, B.; Skorupka, D.; Kuchta, D.; Duchaczek, A. Project risk time management-A proposed model and a case study in the construction industry. Procedia Comput. Sci. 2015, 64, 24-31, doi:10.1016j.procs.2015.08.459.

32. Lalmi, A.; Fernandes, G.; Souad, S.B. A conceptual hybrid project management model for construction projects. Procedia Comput. Sci. 2021, 181, 921-930, doi:10.1016ij.procs.2021.01.248.

33. Lee, K.; Kwon, S.; Shin, J.; Chung, S.; Lee, S. A Prediction method of vertical lifting loads based on long-term time series analysis for high-rise building construction. Procedia Eng. 2017, 196, 121-127, doi:10.1016ij.proeng.2017.07.181.

34. Eckles, R.W. Business Marketing Management: Marketing of Business Products and Service; Prentice-Hall: Upper Saddle River, NJ, USA, 1990

35. Raadt, B.V.D.; Bonnet, M.; Schouten, S.; Vliet, H.V. The relation between EA effectiveness and stakeholder satisfaction. J. Syst. Softw. 2010, 83, 1954-1969.

36. Martin, F.; Hemmelmayr, V.C.; Wakolbinger, T. Integrated express shipment service network design with customer choice and endogenous delivery time restrictions. Eur. J. Oper. Res. 2021, 294, 590-603, doi:10.1016ij.ejor.2021.02.014.

37. Pelli, P. Service innovation and sustainable construction: Analyses of wood vis-à-vis other construction projects. Clean. Eng. Technol. 2021, 2, 100061, doi:10.1016ij.clet.2021.100061(CrossRef).

38. Perez-Vega, R.; Kaartemo, V.; Lages, C.R.; Borghei Razavi, N.; Männistö, J. Reshaping the contexts of online customer engagement behavior via artificial intelligence: A conceptual framework. J. Bus. Res. 2021, 129, 902-910.

39. Benton, W.C.; McHenry, L.F. Construction Purchasing \& Supply Chain Management; McGraw-Hill: New York, NY, USA, 2010.

40. Walker, D.; Hampson, K. Enterprise networks, partnering and alliancing. In Procurement Strategies; Wiley: Hoboken, NJ, USA, 2008; pp. 30-73.

41. Tatari, O.; Skibniewski, M. Integrated agent-based construction equipment management: Conceptual design. J. Civ. Eng. Manag 2006, 12, 231-236, doi:10.3846/13923730.2006.9636397.

42. Ajayi, S.O.; Oyedele, L.O. Waste-efficient materials procurement for construction projects: A structural equation mod-elling of critical success factors. Waste Manag. 2018, 75, 60-69.

43. Ismail, F.; Baharuddin, H.E.A.; Marhani, M.A. Factors Towards site management improvement for industrialised building system (IBS) construction. Procedia Soc. Behav. Sci. 2013, 85, 43-50, doi:10.1016ij.sbspro.2013.08.336

44. Lorenzo, T.M.; Benedetta, B.; Manuele, C.; Davide, T. BIM and QR-code. A synergic application in construction site management. Procedia Eng. 2014, 85, 520-528, doi:10.1016/j.proeng.2014.10.579.

45. Maier, M.; Hein, M.; Von Luxburg, U. Optimal construction of k-nearest neighbor graphs for identifying noisy clusters. Theor Comput. Sci. 2009, 410, 1749-1764.

46. Cakmak, E.; Cakmak, P.I. An analysis of causes of disputes in the construction industry using analytical network process Procedia Soc. Behav. Sci. 2014, 109, 183-187, doi:10.1016j.jbspro.2013.12.441.

47. Elziny, A.; Mohamadien, M.; Ibrahim, H.; Fattah, M.A. An expert system to manage dispute resolutions in construction projects in Egypt. Ain Shams Eng. J. 2016, 7, 57-71, doi:10.1016ij.asej.2015.05.002.

48. Yang, Z. The study on law disputes in construction project contract relationship. Phys. Procedia 2012, 33, 1999-2004, doi:10.1016/j.phpro.2012.05.314.

49. Zimmermann, J.; Eber, W. Criteria on the value of expert's opinions for analyzing complex structures in construction and real estate management. Procedia Eng. 2017, 196, 335-342, doi:10.1016ij.proeng.2017.07.208.

50. Thai Contractors Association under H.M. the King's Patronage. Thailand Construction Handbook; ASEAN Construction Federation: Bangkok, Thailand, 2015.

51. Milat, M.; Knezic, S.; Sedlar, J. A new surrogate measure for resilient approach to construction scheduling. Procedia Comput. Sci. 2021, 181, 468-476, doi:10.1016ij.procs.2021.01.192.

52. Åsgård, T.; Jørgensen, L. Health and safety in early phases of project management in construction. Procedia Comput. Sci. 2019, 164, 343-349, doi:10.1016/j.procs.2019.12.192.

53. Yoon, S.J.; Lin, H.K.; Chen, G.; Yi, S.; Choi, J.; Rui, Z. Effect of occupational health and safety management system on work-related accident rate and differences of occupational health and safety management system awareness between managers in South Korea's construction industry. Saf. Health Work. 2013, 4, 201-209, doi:10.1016ij.shaw.2013.10.002

54. Azhar, S. Role of visualization technologies in safety planning and management at construction jobsites. Procedia Eng. 2017, 171, 215-226, doi:10.1016/j.proeng.2017.01.329.

55. Abou-Senna, H.; Radwan, E.; Navarro, A.; Abdelwahab, H. Integrating transportation systems management and op-erations into the project life cycle from planning to construction: A synthesis of best practices. J. Traffic Transp. Eng. 2018, 5, 44-55.

56. Borodin, A.; Prokofieva, E.; Panin, V.; Erofeev, A. Hybrid intelligent systems of cooperative transportation planning. Transp. Res Procedia 2021, 54, 92-103, doi:10.1016ij.trpro.2021.02.052.

57. Dobromirov, V.; Meike, U.; Evtiukov, S.; Bardyshev, O. Safety of transporting granular road construction materials in urban environment. Transp. Res. Procedia 2020, 50, 86-95, doi:10.1016ij.trpro.2020.10.011. 
58. Ballesteros-Pérez, P.; del Campo-Hitschfeld, M.L.; Mora-Melià, D.; Domínguez, D. Modeling bidding competitiveness and position performance in multi-attribute construction auctions. Oper. Res. Perspect. 2015, 2, 24-35, doi:10.1016ij.orp.2015.02.001.

59. Wang, Y.; Yan, J.; Tseng, M. An auction based negotiation protocol for resource allocation in customized housing construction. Procedia CIRP 2015, 28, 161-166, doi:10.1016ij.procir.2015.04.027.

60. Barkley, A.; Groeger, J.R.; Miller, R.A. Bidding frictions in ascending auctions. J. Econ. 2021, 223, 376-400, doi:10.1016ij.jeconom.2019.11.009.

61. Shahhosseini, V.; Sebt, M. Competency-based selection and assignment of human resources to construction projects. Sci. Iran. 2011, 18, 163-180, doi:10.1016ij.scient.2011.03.026

62. Marin, G.D., Nilă, C. Branding in social media. Using LinkedIn in personal brand communication: A study on communications/marketing and recruitment human resources specialist perception. Soc. Sci. Humanit. Open 2021, 4, 100174

63. Jatobá, M.; Santos, J.; Gutierriz, I.; Moscon, D.; Fernandes, P.O.; Teixeira, J.P. Evolution of artificial intelligence research in human resources. Procedia Comput. Sci. 2019, 164, 137-142.

64. Nowotarski, P.; Paslawski, J.; Matyja, J. Improving construction processes using lean management methodologies-Cost case study. Procedia Eng. 2016, 161, 1037-1042, doi:10.1016/j.proeng.2016.08.845. 